\title{
Effect of climate change on the potential distribution of Heloderma alvarezi (Squamata, Helodermatidae)
}

\author{
Aarón Gómez-Cruz ${ }^{1,2}$, Nancy G. Santos-Hernández', José Alberto Cruz ${ }^{3}$, \\ Daniel Ariano-Sánchez ${ }^{4}$, Christian Ruiz-Castillejos', \\ Eduardo E. Espinoza-Medinilla', José A. De Fuentes-Vicente'
}

\begin{abstract}
I Laboratorio de Investigación y Diagnóstico Molecular (LIDiaM), Instituto de Ciencias Biológicas, Universidad de Ciencias y Artes de Chiapas, Tuxtla Gutiérrez, Chiapas, México 2 Red Mesoamericana y del Caribe para la Conservación de Anfibios y Reptiles, Tuxtla Gutierrez, Mexico 3 Centro Universitario Tenancingo, Universidad Autónoma del Estado de México, México 4 Centro de Estudios Ambientales y Biodiversidad, Universidad Del Valle de Guatemala, Guatemala
\end{abstract}

Corresponding author: José A. De Fuentes-Vicente (jose.defuentes@unicach.mx),

Nancy G. Santos-Hernández (nancy.santos@unicach.mx)

Academic editor: Aaron Bauer | Received 27 May 2021 | Accepted 3 October 2021 | Published 10 November 2021

http://zoobank.org/93C7A758-017E-4C2C-BE1B-B0D52D318B50

Citation: Gómez-Cruz A, Santos-Hernández NG, Cruz JA, Ariano-Sánchez D, Ruiz-Castillejos C, EspinozaMedinilla EE, De Fuentes-Vicente JA (2021) Effect of climate change on the potential distribution of Heloderma alvarezi (Squamata, Helodermatidae). ZooKeys 1070: 1-12. https://doi.org/10.3897/zookeys.1070.69186

\begin{abstract}
Climate change represents a real threat to biodiversity conservation worldwide. Although the effects on several species of conservation priority are known, comprehensive information about the impact of climate change on reptile populations is lacking. In the present study, we analyze outcomes on the potential distribution of the black beaded lizard (Heloderma alvarezi Bogert \& Martin del Campo, 1956) under global warming scenarios. Its potential distribution, at present and in projections for the years 2050 and 2070, under both optimistic and pessimistic climate change forecasts, were computed using current data records and seven bioclimatic variables. General results predict a shift in the future potential distribution of $H$. alvarezi due to temperature increase. The optimistic scenario $\left(4.5 \mathrm{~W} / \mathrm{m}^{2}\right)$ for 2070 suggests an enlargement in the species' distribution as a response to the availability of new areas of suitable habitat. On the contrary, the worst-case scenario $\left(7 \mathrm{~W} / \mathrm{m}^{2}\right)$ shows a distribution decrease by $65 \%$. Moreover, the range distribution of $H$. alvarez $i$ is directly related to the human footprint, which consequently could magnify negative outcomes for this species. Our research elucidates the importance of conservation strategies to prevent the extinction of the black beaded lizard, especially considering that this species is highly threatened by aversive hunting.
\end{abstract}

Copyright Aarón Gómez-Cruz et al. This is an open access article distributed under the terms of the Creative Commons Attribution License (CC BY 4.0), which permits unrestricted use, distribution, and reproduction in any medium, provided the original author and source are credited. 


\section{Keywords}

Climatic change, beaded lizard, conservation, Chiapas, México

\section{Introduction}

In the coming years, the impacts of climate change are projected to play a critical role in global biodiversity dynamics. Since 1980, rainfall and runoff levels at a global scale have decreased annually, which causes an overall prolongation of the dry season and affects entire biomes and ecosystems (Chou et al. 2012). The temperature of the planet has increased by approximately $1.1^{\circ} \mathrm{C}$ since the pre-industrial period, and it is expected to have increased by $4.1^{\circ} \mathrm{C}$ by the end of this century if current emission trends continue unchanged (Hidalgo et al. 2013; IPCC 2014; Masson-Delmote et al. 2018). In addition, deforestation, extractive activities, and the introduction of invasive species might contribute to the increasing negative effects on biodiversity (Durán et al. 2020).

Adaptative and geographic expansion responses of each group of organisms are crucial in determining their preservation or extinction. Accelerated global warming is causing the eradication of a significant proportion of the global reptile diversity (Sinervo et al. 2010; Durán et al. 2020). Due to their high species-richness, lizards constitute a major group of conservation concern (e.g., Sinervo et al. 2010; DieleViegas et al. 2020; Rozen-Rechels et al. 2020). In Mexico, research studies focusing on the effects of climate change on reptiles, and specifically on lizards, have been increasing in the last decade (e.g., Sinervo et al. 2017; Lara-Reséndiz et al. 2019, 2021; Domínguez-Guerrero et al. 2020; Gadsden et al. 2020). Nevertheless, studies relating to helodermatids are scarce.

Heloderma alvarezi, commonly known as the black beaded lizard, is one of the least studied Mexican lizards; hence, the impacts of climate change on this species are not well understood. However, the negative outcomes for helodermatids, given their sensitivity to temperature fluctuations, have been documented (Aranda-Coello et al. 2019; Ariano-Sánchez et al. 2020). For example, high temperatures may lead to fatal physiological alterations such as water loss and an elevated heart rate (DeNardo et al. 2004; Labra et al. 2008). In Mexico, the black beaded lizard has been reported in the Isthmus of Tehuantepec in the southern state of Oaxaca, the central lowlands of Chiapas, and on the border with Guatemala. Moreover, its presence was identified in the Nentón River Valley region of western Guatemala (Álvarez del Toro 1972; Ariano 2011). A lack of information makes it difficult to accurately determine the geographic distribution and conservation status of this species.

This study aimed to determine the potential geographical distribution of $H$. alvarezi, and to estimate the projected scenarios for 2050 and 2070 considering predicted climate change. Assessing the distribution of this species and the long-term environmental effects will allow us to understand its spatiotemporal variation, and to design effective conservation strategies for this species. 


\section{Materials and methods}

\section{Heloderma alvarezi point locality data}

Heloderma alvarezi distribution data were collected between January and June 2020 from several bibliographic databases. These included GBIF (GBIF.org), Naturalista (naturalista.mx), VertNet (vertnet.org), and technical publications from the gray literature (Ariano 2011). To remove duplicate record entries and sampling errors, the data were filtered with the Wallace 1.0.6.1 software (Kass et al. 2018). Points were thinned to a distance of $1 \mathrm{~km}$ to avoid an overfitting in the modeling (e.g., Borzeé et al. 2019). In this way, a total of 27 records of $H$. alvarezi was obtained (Fig. 1).

\section{Climate modeling and prediction with all $H$. alvarezi distribution data}

The Maximum Entropy (Maxent) approach (Philips et al. 2006, 2017) was used to model suitable potential areas for $H$. alvarezi under current and future climatic conditions based on presence-only observations of the species. According to the presence records of $H$. alvarezi used in our analyses, the biogeographical provinces Sierra Madre, Central Plateau, and Central Depression in Chiapas State, Mexico (Morrone 2019) were considered as the species' accessible area $(M)$ (Soberón \& Peterson 2005). Climate modeling was performed at a 30 arc-second resolution with WorldClim2 climate data for 1950-2000 (Fick and Hijmans 2017). Pearson's correlation coefficient was calculated for the 19 bioclimatic variables to evaluate multicollinearity, and to reduce uncertainty in the species distribution models (Elith et al. 2011; Cruz-Cárdenas et al. 2014). One variable was removed from any pair of variables with greater than $80 \%$ correlation, leaving seven bioclimatic variables to be used in the final models (Table 1). Ecological niche models were performed using the Maximum Entropy algorithm implemented in the Maxent v. 3.4.1 software. This software has been demonstrated to generate accurate predictions even when small sample sizes are used (Philips et al. 2006; Pearson et al. 2007; Martínez-Méndez et al. 2016).

Niche models were projected to future scenarios for the years 2041-2060 and 2061-2080 using a GCM MIROC 6 model under different Representative Concentration Pathways (RCPs). Models were evaluated under simulated radiative forcings of 4.5 and $7 \mathrm{~W} / \mathrm{m}^{2}$ to develop optimistic and pessimistic climate change forecasts, respectively (Lara-Reséndiz et al. 2019; Pérez 2020). To determine anthropogenic impact on the distribution of $H$. alvarezi, a carbon footprint estimation layer was overlaid on the niche models generated (Venter et al. 2016, 2018). The carbon footprint was obtained using cumulative emissions for the period 1993-2009, derived from population density, electrical power infrastructure, cultivable land areas, grasslands, roads, and railways (Venter et al. 2016, 2018).

Predictive accuracy was evaluated using the area under the curve (AUC). This can range in value from 0 to 1 . A value less than 0.5 signifies that the classifier performs worse than a random classifier (Felicísimo et al. 2011; Mateo et al. 2011; Santillan 


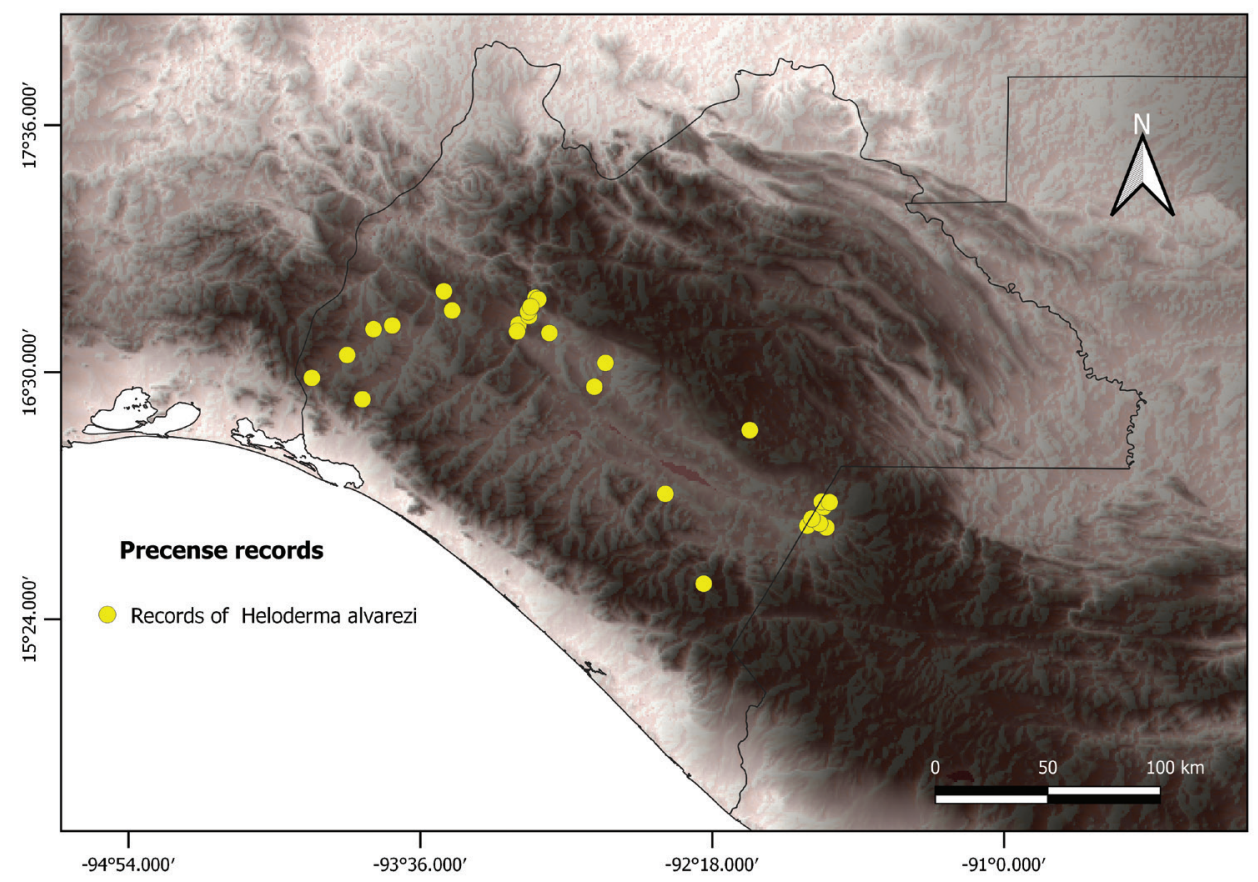

Figure I. Presence records of $H$. alvarezi (yellow dots). Darker zones on grayscale indicate a higher altitude.

2013). The model with the highest statistical significance (AUC $=0.972)$ was selected. Model outputs were exported to QGIS 3.6.3 (QGIS.org 2020) and thresholded to 10\% (Mejía et al. 2018), creating a binary distribution map where non-suitable areas are represented as zero (0) and suitable areas as one (1).

\section{Results}

The current potential distribution model covered a range of $11,218.63 \mathrm{~km}^{2}$, specifically across the Central Depression of Chiapas and the border with Guatemala (Fig. 2). The area of suitability increased at higher altitudes, from 400 to $1000 \mathrm{~m}$ a.s.l. Most of the distribution of the black beaded lizard is delimited by geographical barriers, such as the large mountain ranges that surround the valleys of the Central Depression in Mexico and Guatemala.

Distribution models projected to the future for $H$. alvarezi show variations according to the case scenario and year. The distribution decreases by $12 \%$ for the optimistic scenario in 2050, compared with the current distribution. By 2070, the distribution is expected to increase by $61 \%$ with a displacement towards altitudes between 800 and $2000 \mathrm{~m}$, mainly in the Sierra Madre de Chiapas. On the other hand, pessimistic scenarios for 2050 exhibit an increased distribution of $H$. alvarezi (32\%), although predictions for 2070 reveal a reduction of $65.5 \%$ (Fig. 3). 
Table I. Bioclimatic variables and their contribution to model projections.

\begin{tabular}{|c|c|c|c|}
\hline Acronym & Variable & Percentage contribution & Permutation importance \\
\hline Bio10 & Mean temperature of warmest quarter & 31.1 & 34.2 \\
\hline Biol5 & Precipitation seasonality & 30 & 4.7 \\
\hline Biol7 & Precipitation of driest quarter & 20.9 & 46.2 \\
\hline Bio2 & Mean diurnal range & 15.4 & 12.6 \\
\hline Bio3 & Isothermality & 1.9 & 0.2 \\
\hline Bio4 & Temperature seasonality & 0.7 & 1.9 \\
\hline Bio18 & Precipitation of warmest quarter & 0.1 & 0.3 \\
\hline
\end{tabular}

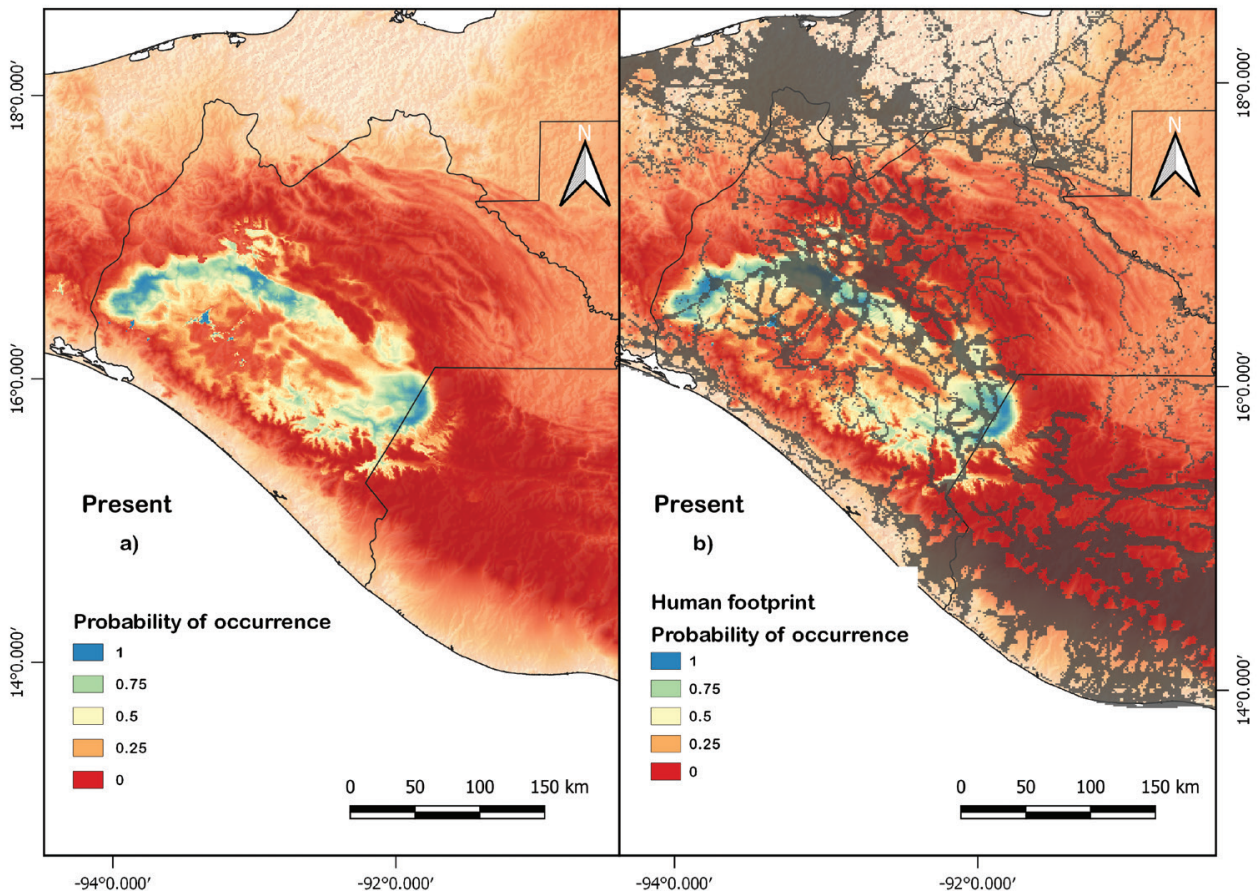

Figure 2. Current potential distribution model of $H$. alvarezi at present (a) and overlaid with human footprint (b).

\section{Discussion}

According to our present-day distribution models, the distribution area of $H$. alvarezi extends over 11,218.63 $\mathrm{km}^{2}$ in the Central Chiapas Depression in Mexico and the Nentón River Valley in Guatemala. These areas are highly fragmented by human activity, which could induce individuals to settle where the impact of the human footprint is less pronounced, mainly on the borders of the Sierra Madre de Chiapas. This distribution excludes the regions of Socotelnango and La Concordia (Mexico) due to inappropriate environmental conditions (Suppl. material 1). Except for H. charlesbogerti (Campbell \& Vannini, 1988), the distribution of $H$. alvarezi is the most restricted of any species in the Family Helodermatidae (Ariano 2007). The areas of high elevation in the Isthmus of Tehuantepec may act as a barrier that restricts the distribution of H. alvrezi in the direction of Oaxaca (Domínguez-Vega et al. 2012). 


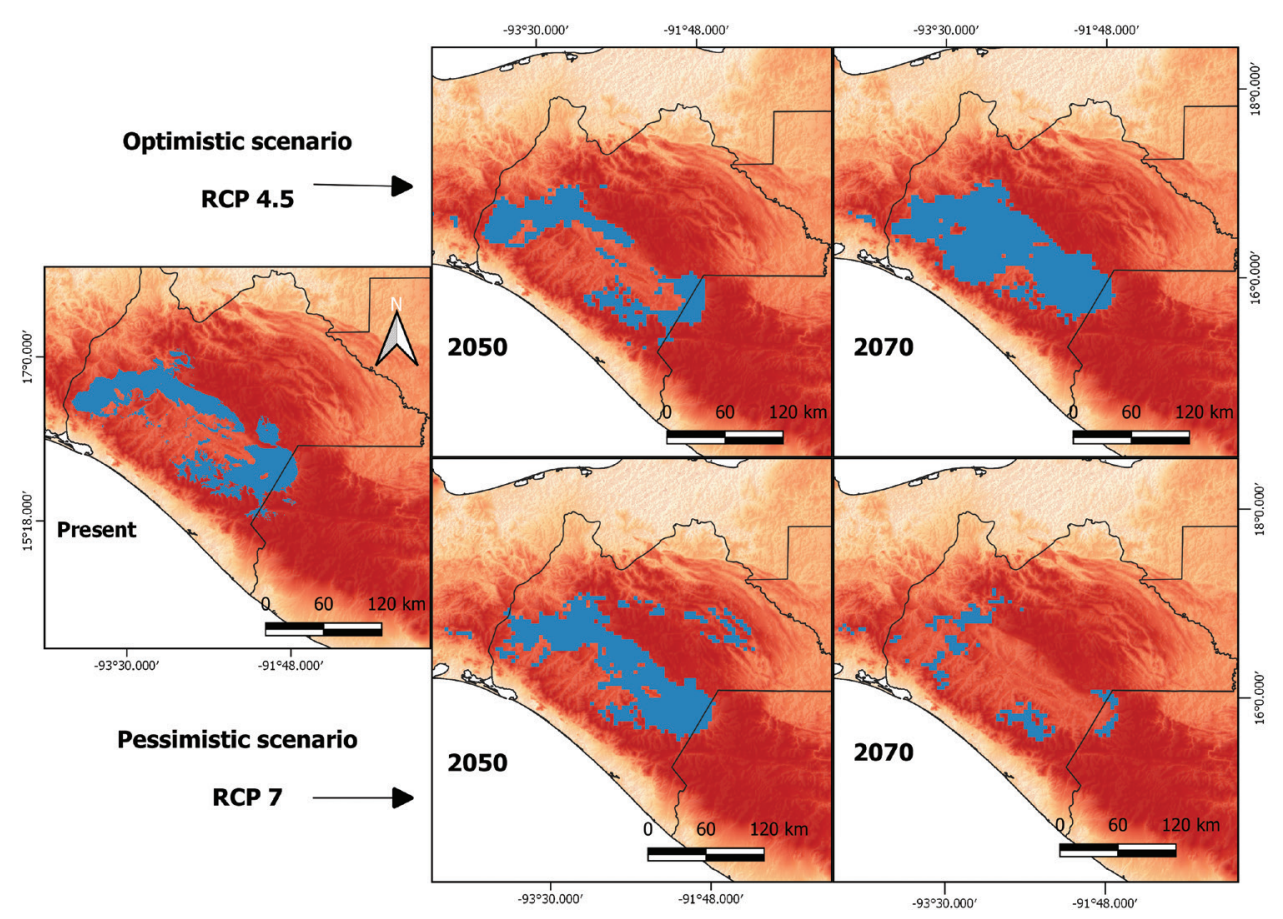

Figure 3. Potential distribution of $H$. alvarezi under different climate change scenarios using different Representative Concentration Pathways (RCP) and the seven bioclimatic variables that best explain the potential distribution of $H$. alvarezi.

Our results suggest that $H$. alvarezi is found principally in seasonally tropical dry forests (SDTF), categorized as a highly threatened ecosystem (Trejo and Dirzo 2000; Trejo 2010). Over 30\% of forest loss in Chiapas has been prompted by anthropic activities (Rocha et al. 2010). In addition to deforestation of the ecosystem, the aversive hunting of helodermatids may play an important role in their current distribution. Hunting intensity may be greater where the species distribution overlaps with the human footprint, although data are lacking. Historically, hunting, which threatens their distribution and abundance (Fig. 2a) (Aranda-Coello et al. 2019), has been carried out because of the appearance of these lizards and myths about their venom, as well as for the illegal skin trade.

Because projected distribution maps predict future implications of climate change on a species' conservation status, these climatic forecasts enable us to take forwardthinking actions. The seven highest-contributing bioclimatic variables in the potential distribution modeling of $H$. alvarezi, in order, were: mean temperature of warmest quarter (Bio10), precipitation seasonality (Bio15), precipitation of driest quarter (Bio17) and mean diurnal range (Bio2). These are consistent with the findings of DomínguezVega et al. (2012) on the distribution of the genus Heloderma. It is important to mention that these models do not consider additional factors, such as aversive hunting (killing by local communities due to fear of their poisonous nature) (Domínguez-Vega et al. 2017). Hence, further research might examine these conditions. 
When the human footprint layer was overlaid on the present-day distribution model of $H$. alvarezi, it may be seen that anthropogenic impact could be considerable. It has been observed with other organisms that human population growth, roads, and changes in land use affect an organism's existence, especially by the occupation and transformation of the landscape, the alteration of the habitat and dispersal of physicochemical pollutants (Beck 2005; Colino-Rabanal and Lizana 2012; Pitts et al. 2017). However, not all species will have the same degree of exposure to the human impact, as this depends on taxon-specific ecological requirements (Colino-Rabanal and Lizana 2012).

According to our climate change scenarios, under an optimistic scenario (RCP 4.5) the distribution of the lizard would decrease by 2050, however, a substantial increase in projected distribution range is expected by 2070 . This increase in distribution is expected towards the Sierra Madre de Chiapas, where perhaps suitable bioclimatic conditions for $H$. alvarezi are expected. Environmental factors (i.e., temperature and humidity) affect the species' behavior and its habitat selection (Labra et al. 2008; Sinervo et al. 2018; Altamirano-Benavides et al. 2019).

As expected, the most unfavorable conditions to $H$. alvarezi will occur under a pessimistic scenario. This model projects a reduction in the distribution range by 65\%; this percentage is higher compared to other Heloderma, such as H. suspectum (Giermanowsky et al. 2018), but similar to those of other lepidosaurs (see GüizadoRodríguez et al. 2012). It is proposed that this scenario will lead to a decrease in precipitation and humidity, and would cause alterations in the species' behavior. We know that the prolonged length of the aestivation period of these lizards ends with the arrival of the rainy period (Domínguez-Vega et al. 2012; Aranda-Coello et al. 2019; Ariano-Sánchez et al. 2020).

In addition, the rainy season begins the foraging and reproduction activity of the helodermatids, so a prolonged dry season would cause alterations in the population structure of these lizards (Ariano-Sánchez et al. 2020). Sinervo et al. (2010) suggested a probability of $91 \%$ for the extinction of Helodermatidae by 2080; this projection is consistent with our estimations for a pessimistic scenario. For some species, the process of adaptation to environmental changes is mostly slow and the ability to withstand climatic variations is limited (Foden et al. 2007). Rapid environmental changes and anthropogenic effects will be crucial to the survival of this species and could exacerbate the effects of range reduction. Analogously, the lack of knowledge about the thermal ecology of $H$. alvarezi in the wild is an important constraint on understanding its adaptability (Aranda-Coello et al. 2019). Therefore, it could be usefully explored in further research.

The implementation of conservation programs for species highly sensitive to climate change is fundamental. The present study suggests that the future of the black beaded lizard is not encouraging under different climate change scenarios. Promoting structural and functional connectivity among the remaining SDT patches and their associated mesic conditions is the most effective weapon to facilitate the altitudinal and latitudinal migration of the species under a global warming forecast. Additionally, slowing down climate change constitutes a primary focus on conservation status for the organisms living in xeric ecosystems, included $H$. alvarezi. 


\section{References}

Altamirano-Benavides MA, Domínguez-Guerrero SF, Muñoz-Nolasco FJ, Arenas-Moreno DM, Santos-Bibiano R, Gómez-Trejo R, Lozano-Aguilar LE, Fierro-Estrada N, Gandarrilla-Aizpuro FJ, Woolrich-Piña GA, Martínez-Méndez N, Lara-Reséndiz RA, Méndez-de la Cruz FR (2019) Ecología térmica y riesgo de extinción ante el cambio climático de Gonatodes concinnatus (Squamata: Sphaerodactylidae), una lagartija endémica de la Amazonía occidental. Revista Mexicana de Biodiversidad 90: 1-12. https://doi.org/10.22201/ ib.20078706e.2019.90.2824

Álvarez A, Raymundo V, Ruiz JA, Santiago-Pérez AL (2020) Efecto del cambio climático a partir de los escenarios RCP 4.5 y 8.5 del año 2050 en el balance hídrico del Área Natural Protegida La Primavera, Jalisco, México. Áreas Naturales Protegidas Scripta 6: 53-74. https://doi.org/10.18242/anpscripta.2020.06.06.01.0004

Álvarez del Toro M (1972) Los reptiles de Chiapas. Publicación del Instituto de Historia Natural, Tuxtla Gutiérrez, Chiapas, México.

Aranda-Coello JM, Gómez A, Mendoza OM, Reyes E (2019) Termorregulación en el comportamiento de Heloderma alvarezi (Squamata: Helodermatidae) en cautiverio. Revista Latinoamericana de Herpetología 2: 41-46.

Ariano D (2007) Distribución potencial, ámbitos de hogar y patrones de comportamiento del Lagarto Escorpión Heloderma horridum charlesbogerti (Sauria: Helodermatidae) con notas sobre el primer reporte de caso de envenenamiento por esta especie en Guatemala. Tesis de Maestría. Universidad de Costa Rica

Ariano D (2011) Distribución, ecología, evaluación y desarrollo de estrategias para la conservación del Escorpión negro (Heloderma horridum alvarezi) en los bosques secos de Guatemala. FONACYT. Accessed 03 March 2020 from: https://fondo.senacyt.gob.gt/portal/ index.php/catalogo/15-codigo/568-08-2011-medio-ambiente.

Ariano-Sánchez D, Mohr R, Reinhardt S, Rosell F (2020) Escaping drought: Seasonality effects on home range, movement patterns and habit selection of the Guatemalan Beaded Lizard. Global Ecology and Conservation 23: 1-13. https://doi.org/10.1016/j.gecco.2020.e01178

Borzée A, Choi Y, Kim YE, Jablonski PG, Jang Y (2019) Interspecific variation in seasonal migration and brumation behavior in two closely related species of treefrogs. Frontiers in Ecology and Evolution 7: 1-16. https://doi.org/10.3389/fevo.2019.00055

Ceballos G, Martínez L, García A, Espinoza E, Bezaury J, Dirzo R (2010) Diversidad, amenazas y áreas prioritarias para la conservación de las selvas bajas del Pacífico de México. En CONABIO. Trejo, I. (primera edición) Las selvas secas del Pacífico Mexicano. Ciudad de México, México. pp. 41-51

Chou C, Chen C, Tan P, Chen KT (2012) Mechanisms for global warming impacts on precipitation frequency and intensity. Journal of Climate 25: 3291-3306. https://doi. org/10.1175/JCLI-D-11-00239.1

Colino-Rabanal VJ, Lizana M (2012) Herpetofauna and roads: a review. Basic and Applied Herpetology 25: 5-31. https://ojs.herpetologica.org/index.php/bah/article/view/12

Cruz-Cárdenas G, Villaseñor JL, López-Mata L, Martínez-Meyer E, Ortiz E (2014) Selección de predictores ambientales para el modelado de la distribución de las especies en Maxent. 
Revista Chapingo. Serie Ciencias Forestales y del Ambiente 20: 187-201. DOI:10.5154/r. rchscfa.2013.09.034

DeNardo DF, Zubal TE, Hoffman TC (2004). Cloacal evaporative cooling: a previously undescribed means of increasing evaporative water loss at higher temperatures in a desert ectotherm, the Gila monster Heloderma suspectum. The Journal of Experimental Biology 207: 945-953. https://doi.org/10.1242/jeb.00861

Diele-Viegas L, Figueroa RT, Viela B, Duarte CF (2020) Are reptiles toast? A worldwide evaluation of Lepidosauria vulnerability to climate change. Climate Change 159: 581-599. https://doi.org/10.1007/s10584-020-02687-5

Domínguez-Guerrero S, Bodensteiner, BL, Pardo-Ramírez A, Aguillón-Gutiérrez AR, Méndezde la Cruz FR, Muñoz, MM (2020) Thermal physiology responds to interannual temperature shifts in a montane horned lizard, Phrynosoma orbiculare. Journal of Experimental Zoology 335: 1-10. https://doi.org/10.1002/jez.2403

Domínguez-Vega H, Monroy-Vilchis O, Balderas-Valdivia CJ, Gienger CM, Ariano-Sánchez D (2012) Predicting the potential distribution of the beaded lizard and identification of priority areas for conservation. Journal for Nature Conservation 20: 247-253. http:// dx.doi.org/10.1016/j.jnc.2012.04.003

Domínguez-Vega H, Monroy-Vilchis O, Manjarrez J, Balderas-Valdivia CJ (2017) Aversive hunting and frequency ecology of Beaded lizards (Squamata: Helodermatidae). Perspectives in Ecology and Conservation 15: 47-51. http://dx.doi.org/10.1016/j. pecon.2016.11.003

Durán PN, Loya JL, Ruiz JA, González DR, García JD, Martínez S, Crespo MR (2020). Impacto del cambio climático en la distribución potencial de Tithonia diversifolia (Hemsl.) A. Gray en México. Revista Mexicana de Ciencias Pecuarias 11: 93-106. https://doi. org/10.22319/rmcp.v11s2.4705

Elith J, Philips SJ, Hastie T, Dudík M, Chee YE, Yates J (2011) A statistical explanation of Maxent for ecologists. Diversity and Distributions 17: 43-57. https://doi.org/10.1111/ j.1472-4642.2010.00725.x

Felicísimo AM, Muñoz J, Villalba CJ, Mateo RG (2011) Impactos del cambio climático sobre la flora española. Conservación Vegetal 15: 6-10.

Fick SE, Hijmans RJ (2017) WorldClim2: new 1-km spatial resolution climate surfaces for global land areas. International Journal of Climatology 37: 4302-4315. https://doi. org/10.1002/joc.5086

Foden W, Midgley GF, Hughes G, Bond WJ, Thuiller W, Hoffman MT, Kaleme P, Underhill LG, Rebelo A, Hannah L (2007) A changing climate is eroding the geographical range of the Namib Desert tree aloe through population declines and dispersal lags. Diversity and Distributions 13: 645-653. https://doi.org/10.1111/j.1472-4642.2007.00391.x

Gadsden H, Lara-Reséndiz RA, Minjarrez-Flores NF, Gatica-Colima A, Smith GR (2020) Thermoregulation in a saxicolous population of the lizard Urosaurus ornatus from the northern Chihuahua Desert, Mexico. Amphibia-Reptilia 42:153-166: 1-14. https://doi. org/10.1163/15685381-bja10037

GBIF.org (2021) GBIF Occurrence Download. Accessed 16 August 2019 from: https://doi. org/10.15468/dl.unfegz. 
Giermakowski JT, Ryan M, Latella I (2018) Evaluation of the distribution and conservation status of the Gila Monster (Heloderma suspectum) in southwestern New Mexico Final Report.. Consulted 16 August 2020 from: https://www.wildlife.state.nm.us/download/ conservation/share-with-wildlife/reports/2017/Evaluation-of-the-distribution-and-conservation-status-of-the-Gila-monster-Heloderma-suspectum-in-southwest-New-Mexico_-Tom-Giermakowski.pdf

Güizado-Rodríguez MA, Ballesteros-Barrera C, Casas-Andreu G, Téllez-Valdés O, SalgadoUgarte IH (2012) The impact of global warming on the range distribution of different climatic groups of Aspidocelis costata costata. Zoological Science 29: 834-843. https://doi. org/10.2108/zsj.29.834

Hidalgo HG, Amador JA, Alfaro EJ, Quesada B (2013) Hydrological climate change projections for Central America. Journal of Hydrology 495: 94-112. 10.1016/j.jhydrol.2013.05.004

Intergovernmental Panel on Climate Change (2014). Climate Change 2014 - Impacts, Adaptation and Vulnerability: Part A: Global and Sectoral Aspects: Working Group II Contribution to the IPCC Fifth Assessment Report. Cambridge: Cambridge University Press. https://doi.org/10.1017/CBO9781107415379

Kass JM, Vilela B, Aiello-Lammens ME, Muscarella R, Merow C, Anderson RP (2018) Wallace: A flexible platform for reproducible modeling of species niches and distributions built for community expansion. Methods in Ecology and Evolution 9: 1151-1156. https://doi. org/10.1111/2041-210X.12945

Labra A, Vidal MA, Solís R, Penna M (2008) Ecofisiología de anfibios y reptiles. In: Vidal MA, Labra A (eds) Herpetología de Chile. Science. Verlag, Santiago de Chile, Chile, pp. 483-516.

Lara-Reséndiz R, Galina-Tessaro P, Pérez-Delgadillo AG, Valdez-Villavicencio JH, Méndez-de la Cruz FR (2019) Efecto del cambio climático en una especie de lagartija termófila de amplia distribución (Dipsosaurus dorsalis): un enfoque ecofisiológico. Revista Mexicana de Biodiversidad 90: 1-11. https://doi.org/10.22201/ib.20078706e.2019.90.2888

Lara-Reséndiz R, Galina-Tessaro P, Sinervo B, Miles DB, Valdez-Villavicencio JH, Valle-Jiménez FI, Méndez-de la Cruz FR (2021) How will climate change impact fossorial lizard species? Two examples in the Baja California Peninsula. Journal of Thermal Biology 95. https://doi.org/10.1016/j.jtherbio.2020.102811

Martínez-Mendez N, Aguirre-Planter E, Eguiarte LE, Jaramillo-Correa JP (2016) Modelado de nicho ecológico de las especies (Pinaceae) en México: Algunas implicaciones taxonómicas y para la conservación. Botanical Sciences 9: 5-24. DOI: 10.17129/botsci.5008

Masson-Delmote V, Zhai VP, Pörtner HO (2018) Global Warming of $1.5^{\circ} \mathrm{C}$. An IPCC Special Report on the impacts of global warming of $1.5^{\circ} \mathrm{C}$ above pre-industrial levels and related global greenhouse gas emission pathways, in the context of strengthening the global response to the threat of climate change, sustainable development, and efforts to eradicate poverty. IPCC. Accessed 13 April 2020 from: https:/www.ipcc.ch/site/assets/uploads/ sites/2/2019/06/SR15_Full_Report_Low_Res.pdf.

Mateo RG, Felicísimo AM, Muñoz J (2011) Modelos de distribución de especies: Una revisión sintética. Revista Chilena de Historia Natural 84: 217-240. http://dx.doi.org/10.4067/ S0716-078X2011000200008 
Mejía D, Tonon MD, Abad L (2018) Distribución potencial del género Polylepis en la Cuenca del río Paute bajo un escenario de cambio climático. Revista de la Facultad de Ciencias Químicas 19: 21-37.

Morrone JJ (2019) Regionalización biogeográfica y evolución biótica de México: encrucijada de la biodiversidad del Nuevo Mundo. Revista Mexicana de Biodiversidad 90: 1-68. https:// doi.org/10.22201/ib.20078706e.2019.90.2980

Naturalista.mx (2021) CONABIO. Accessed 20 August 2019 from: https://www.naturalista. $\mathrm{mx} /$ taxa/35009-Heloderma-horridum-alvarezi

Pearson RG, Raxworthy CJ, Nakamura M, Peterson AT (2007) Predicting species distributions from small numbers of occurrence records: a test case using cryptic geckos in Madagascar. Journal of Biogeography 34: 102-117. DOI: 10.1111/j.1365-2699.2006.01594.x

Phillips SJ, Anderson RP, Schapire RE (2006) Maximum entropy modeling of species geographic distributions. Ecological Modelling 190: 231-259. https://doi.org/10.1016/j.ecolmodel.2005.03.026

Phillips SJ, Anderson RP, DudÍk M, Schapire RE, Blair ME (2017) Opening the black box: An open-source release of MaxEnt. Ecography 40: 887-893. https://doi.org/10.1016/j. ecolmodel.2005.03.026

Pitts S, Hughes BD, Mali I (2017) Rattlesnake nuisance removals and urban expansion in Phoenix, Arizona. Western North American Naturalist 77: 309-316. https://doi. org/10.3398/064.077.0304

QGIS.org, 2021. QGIS Geographic Information System. QGIS Association. Accessed 20 February 2020 from: http://www.qgis.org.

Rocha, AG, Ramírez N, González-Espinoza M (2010) Riqueza y diversidad de árboles del bosque tropical caducifolio en la depresión central de Chiapas. Boletín de la Sociedad Botánica de México 87: 89-103. https://doi.org/10.17129/botsci.313

Rozen-Rechels D, Rutschmann A, Dupoué A, Blaimont P, Chauveau V, Miles DB, Guillon M, Richard M, Badiane A, Meylan S, Clobert J (2020) Interaction of hydric and thermal conditions drive geographic variation in thermoregulation in a widespread lizard. Ecological Monographs, 91: https://doi.org/10.1002/ecm.1440

Santillán V (2013) Aplicación de sistemas de información geográfica (SIG) para la elaboración de modelos zoogeográficos: un estudio de caso. Universidad del Azauy. Accessed 5 April 2020 from: http://dspace.uazuay.edu.ec/bitstream/datos/3324/1/09343.pdf.

Sinervo B, Lara RA, Miles DB (2017) Climate Change and Collapsing Thermal Niches of Mexican Endemic Reptiles. UC Office of the President: UC-Mexico Initiative. Accessed 16 December 2020 from: https://escholarship.org/uc/item/4xk077hp.

Sinervo B, Méndez de la Cruz F, Miles DB, Heulin B, Bastiaans E, Villagrán-Santa Cruz M, Lara-Resendiz R, Martínez-Méndez N, Calderón-Espinosa ML, Meza-Lázaro RN, Gadsden H, Ávila LJ, Morando M, De la Riva IJ, Sepúlveda PV, Duarte-Rocha CF, Ibargüengoytía N, Aguilar-Puntriano C, Massot M, Lepetz V, Oksanen TA, Chapple DG, Bauer AM, Branch WR, Clobert J, Sites Jr JW (2010) Erosion of lizard diversity by climate change and altered thermal niches. Science 328: 894-899. https://doi.org/10.1126/science.1184695

Sinervo B, Miles DB, Wu Y, Méndez-de la Cruz FR, Kirchhof S, Qi Y (2018) Climate change, thermal niches, extinction risk and maternal-effect rescue of toad-headed lizards, Phryno- 
cephalus, in thermal extremes of the Arabian Peninsula to the Qinghai-Tibetan Plateau. Integrative Zoology 13: 450-470. https://doi.org/10.1111/1749-4877.12315

Soberón J, Peterson AT (2005) Interpretation of models of fundamental ecological niches and species' distributional areas. Biodiversity Informatics 2: 1-10.

Trejo I, Dirzo R (2000) Deforestation of seasonal dry tropical forest a national and local analysis in Mexico. Biological Conservation 94: 133-142. https://doi.org/10.1016/S00063207(99)00188-

3Venter O, Sanderson EW, Magrach A, Allan JR, Beher J, Jones KR, Possingham HP, Laurance WF, Wood P, Fekete BM, Levy MA, Watson JE (2018) Last of the Wild Project, Version 3 (LWP-3): 2009 Human Footprint, 2018 Release. Palisades, NY: NASA Socioeconomic Data and Applications Center (SEDAC). https://doi.org/10.7927/H46T0JQ4

Venter O, Sanderson EW, Magrach A, Allan JR, Beher J, Jones KR, Possingham HP, Laurance WF, Wood P, Fekete BM, Levy MA, Watson JE (2016) Global Terrestrial Human Footprint Maps for 1993 and 2009. Scientific Data 3:16006 https://doi.org/10.1038/sdata.2016.67 VertNet.org (2021) VertNet. Accessed 18 August 2019 from: http://portal.vertnet.org/ search?q=Heloderma+alvarezi

\section{Supplementary material I}

\section{Supplementary figures and table}

Authors: Aarón Gómez-Cruz, Nancy G. Santos-Hernández, José Alberto Cruz, Daniel Ariano-Sánchez, Christian Ruiz-Castillejos1, Eduardo E. Espinoza-Medinilla1, José A.

De Fuentes-Vicente

Data type: species data

Explanation note: Figure S1. Current potential distribution map of $H$. alvarezi with political boundaries. Figure S2. Future potential distribution of $H$. alvarezi with current human footprint projections. Table S3. Heloderma alvarezi presence records used for potential distribution modeling.

Copyright notice: This dataset is made available under the Open Database License (http://opendatacommons.org/licenses/odbl/1.0/). The Open Database License $(\mathrm{ODbL})$ is a license agreement intended to allow users to freely share, modify, and use this Dataset while maintaining this same freedom for others, provided that the original source and author(s) are credited.

Link: https://doi.org/10.3897/zookeys.1070.69186.suppl1 